\title{
PENGARUH KOMPENSASI, GAYA KEPEMIMPINAN DAN IKLIM ORGANISASI TERHADAP KINERJA KARYAWAN LP3I KARANG TENGAH, CILEDUG
}

\author{
Yhonanda Harsono. S. Si., M. M \\ Dosen Fakultas Ekonomi Universitas Pamulang \\ Email : $\underline{\text { Yhonanda2906@gmail.com }}$
}

\begin{abstract}
ABSTRAK
Lembaga Pendidikan dan Pengembangan Profesi Indonesia (LP3I) didirikan dengan tujuan untuk membantu para lulusan SMA/SMK yang ingin tetap melanjutkan pendidikannya tetapi juga bisa cepat kerja, karena konsep yang dibuat oleh LP3I adalah konsep tepat dan cepat kerja serta pengembangan skill siswa untuk menghadapi dunia kerja.

LP3I Karang Tengah dipimpin oleh seorang kepala kampus yang merupakan kepala cabang, dimana divisi-divisi yang terdapat di LP3I Karang Tengah adalah divisi marketing, pendidikan, keuangan, IT dan C\&P (Corporate \& Placement). Setiap divisi memiliki staf dan tugas masing-masing yang semua itu merupakan bagian dari manajemen LP3I Karang Tengah, Ciledug. Tetapi melihat dari perkembangan kinerja karyawan setiap tahunnya, kinerja karyawan di LP3I Karang Tengah masih rendah, hal ini dipengaruhi oleh beberapa faktor baik internalmaupun eksternal. Faktor eksternalnya adalah kurangnya dukungan dari atasan, rendahnya fasilitas kerja yang disediakan dan pemberian kompensasi yang tidak sesuai.

Tujuan penelitian ini adalah untuk mengetahui seberapa besar pengaruh secara parsial variabel kompensasi, gaya kepemimpinan dan iklim organisasi terhadap kinerja karyawan LP3I Kampus Karang Tengah. Metode yang digunakan adalah metode survey deskriptif, dimana metode tersebut dilakukan dengan cara pengumpulan data dan melakukan observasi, instrumentasi dan menggunakan studi literatur. Berdasarkan pada penelitian yang telah dilakukan maka hasil yang dicapai pada penelitian ini adalah bahwa LP3I Karang Tengah perlu memperhatikan variabel-variabel yang berkaitan dengan kompensasi guna meningkatkan motivasi kerja karyawan dan juga perlu menciptakan gaya kepemimpinan yang kondusif dan harmonis, karena jika kepemimpinan tidak harmonis maka karyawan akan sulit bekerjasama dengan baik dan ini akan berpengaruh terhadap kinerja karyawan.
\end{abstract}

\section{Kata Kunci: Kompensasi, Gaya Kepemimpinan, Iklim Organisasi, Kinerja}




\section{PENDAHULUAN}

\section{Latar Belakang}

Dalam manajemen perusahaan faktor SDM yaitu karyawan sangatlah berperan penting dalam perkembangan perusahaan, tapi SDM disini perlu adanya motivasi agar kinerjanya terhadap perusahaan maksimal. Beberapa faktor eksternal seperti kurangnya dukungan atasan dan pemberian kompensasi yang tidak sesuai akan mempengaruhi motivasi kerja karyawan.

Lembaga Pendidikan dan pengembangan Profesi Indonesia (LP3I) Karang Tengah merupakan salah satu lembaga pendidikan swasta yang terletak di J1. Raden Saleh no. 2,

Karang Tengah Ciledug. LP3I Karang Tengah ini didirikan dengan tujuan untuk membantu para lulusan SMA/SMK yang ingin tetap melanjutkan pendidikannya tetapi juga bisa cepat kerja, karena konsep yang dibuat oleh LP3I adalah konsep tepat dan cepat kerja serta pengembangan skill siswa untuk menghadapi dunia kerja.

Tujuan dalam Penelitian ini adalah untuk mengetahui seberapa besar pengaruh secara parsial variabel kompensasi dan gaya kepemimpinan terhadap kinerja karyawan di LP3I Kampus Karang Tengah.

\section{Identifikasi Masalah}

Setelah melakukan penelitian pada LP3I Karang Tengah yang merupakan sebuah Lembaga Pendidikan swasta yang sedang berkembang, peneliti merumuskan adanya permasalahan dalam kinerja karyawan di LP3I Kampus Karang Tengah. Maka dari itu masalah yang mendasari penelitian ini adalah sebagai berikut:

1. Kurang adanya standarisasi kompensasi sehingga berdampak pada kinerja karyawan menurun.

2. Kepemimpinan di LP3I Karang Tengah yang masih kurang kondusif sehingga karyawan kurang leluasa dalm bekerjasama.

3. Kepemimpinan yang sering berganti-ganti sehingga mengakibatkan perubahan kebijakan-kebijakan.
4. Kinerja karyawan belum optimal, sehingga pertumbuhan perusahann lambat.

5. Jumlah karyawan yang tidak stabil karena sering terjadinya pengunduran diri karyawan dan penerimaan karyawan dalm satu tahun.

\section{Batasan Masalah}

Berikut ini adalah batasan masalah dari penelitian:

Pada penelitian ini penulis memberikan pembatasan masalah yang ada di LP3I Karang Tengah hanya pada masalah pengaruh kompensasi, gaya kepemimpinan dan iklim organisasi terhadap kinerja karyawan.

\section{Rumusan Masalah}

Dari identifikasi masalah sertaperumusan masalah yang dihasilkan pada penelitian ini adalah:

1. Apakah terdapat pengaruh yang signifikan antara kompensasi terhadap kinerja karyawan LP3I Kampus Karang Tengah, Ciledug

2. Apakah terdapat pengaruh yang signifikan antara gaya kepemimpinan terhadap kinerja karyawan LP3I Kampus Karang Tengah, Ciledug

3. Apakah terdapat pengaruh yang signifikan antara iklim organisasi terhadap kinerja karyawan LP3I Kampus Karang Tengah, Ciledug

4. Apakah terdapat pengaruh yang signifikan variabel kompensasi, gaya kepemimpinan dan iklim organisasi terhadap kinerja karyawan LP3I Kampus Karang Tengah, Ciledug

\section{Tujuan Penelitian}

Berikut ini adalah tujuan yang ingin dicapai dari penelitian :

1. Untuk mengetahui seberapa besar pengaruh secara parsial variabel 
kompensasi terhadap kinerja karyawan LP3I Kampus Karang Tengah, Ciledug

2. Untuk mengetahui seberapa besar pengaruh secara parsial variabel gaya kepemimpinan terhadap kinerja karyawan LP3I Kampus Karang Tengah, Ciledug

3. Untuk mengetahui seberapa besar pengaruh secara parsial variabel iklim organisasi terhadap kinerja karyawan LP3I Kampus Karang Tengah, Ciledug.

4. Untuk mengetahui seberapa besar pengaruh variabel kompensasi, gaya kepemimpinan dan iklim organisasi terhadap kinerja karyawan LP3I Kampus Karang Tengah, Ciledug

\section{Manfaat Penelitian}

Berikut ini merupakan manfaat dari penelitian ini:

Sebagai bahan acuan dan informasi bagi perusahaan untuk mengetahui sejauh mana kompensasi dan gaya kepemimpinan terhadap kinerja karyawan.

Sebagai bahan pertimbangan bagi perusahaan dalam menetapkan formulasi strategi pencapaian kinerja karyawan di LP3I kampus Karang Tengah, Ciledung.

Sebagai bahan acuan dan informasi bagi perusahaan untuk mengetahui sejauh mana kompensasi dan gaya kepemimpinan terhadap kinerja karyawan.

\section{LANDASAN TEORI}

\section{Tinjauan Pustaka \\ Kompensasi}

Kompensasi

merupakan pengeluaran dan biaya bagi perusahaan. Menurut Hasibuan (1989) kompensasi adalah semua pendapatan yang berbentuk uang, barang langsung atau tidak langsung yang diterima karyawan sebagai imbalan jasa yang diberikan dari perusahaan. Kompensasi berbentuk uang, artinya kompensasi dibayar dengan sejumlah uang kartal kepada karyawan bersangkutan. Kompensasi berbentuk barang artinya kompensasi dibayar dengan barang.

Kompensasi dibedakan menjadi dua, yaitu : kompensasi langsung (direct compensation) berupa gaji, upah dan upah sensitif. Kompensasi tidak langsung (inderect compensation) atau employee welfare atau kesejahteraan karyawan.

$$
\text { Program pemberian }
$$

kompensasi atau balas jasa umumnya bertujuan untuk kepentingan perusahaan, karyawan dan pemerintah/masyarakat. Supaya tujuan tercapai dan memberikan kepuasan bagi semua pihak hendaknya program kompensasi ditetapkan berdasarkan prinsip adil dan wajar, undang-undang perburuhan serta memperhatikan internal dan eksternal konsistensi.

Tujuan kompensasi (balas jasa) antara lain adalah sebagai ikatan kerja sama, kepuasan kerja, pengadaan efektif, motivasi stabilitas karyawan, disiplin serta pengaruh serikat buruh dan pemerintah.

Berdasarkan UU No. 21 Tahun 2000 Pasal 2 Tentang Asas Serikat Buruh, bahwa program kompensasi (balas jasa) harus ditetapkan atas asas adil dan layak serta dengan memperhatikan undang-undang perburuhan yang berlaku. Prinsip adil dan layak harus mendapat perhatian dengan sebaik-baiknya supaya balas jasa yang akan diberikan merangsang gairah dan kepuasan kerja karyawan.

Metode kompensasi (balas jasa) dikenal dengan metode tunggal dan metode jamak. 
Metode tunggal yaitu suatu metode yang dalam penetapan gaji pokok hanya didasarkan atas ijazah terakhir dari pendidikan formal yang dimiliki karyawan.

Metode jamak yaitu suatu metode yang dalam gaji pokok didasarkan atas beberapa pertimbangan seperti ijazah, sifat pekerjaan, pendidikan informal bahkan hubungan keluarga ikut menentukan besarnya gaji pokok seseorang.

Sistem pembayaran kompensasi yang umum ditetapkan adalah sistem waktu, sistem hasil (output), dan sistem borongan.

Kebijakan kompensasi dan besarnya kompensasi harus ditetapkan berdasarkan analisis pekerjaan, uraian pekerjaan, spesifikasi pekerjaan, posisi jabatan, peraturan, serta berpedoman kepada keadilan dan undang-undang perburuhan.

Artinya kompensasi harus dibayar tepat pada waktunya, jangan sampai terjadi penundaan, supaya kepercayaan karyawan terhadap bonafiditas perusahaan semakin besar, ketenangan dn konsentrasi kerja akan lebih baik.

Faktor-faktor

yang mempengaruhi besarnya kompensasi, antara lain :Penawaran dan permintaan tenaga kerja, kemampuan dan kesediaan perusahaan, Serikat Buruh, produktifitas kerja karyawan, pemerintah dengan Undang-undang dan Keppres, biaya hidup, posisi jabatan karyawan, pendidikan dan pengalaman kerja, kondisi perekonomian nasional serta jenis dan sifat pekerjaan.

\section{B. Gaya Kepemimpinan}

Definisi kepemimpinan menurut beberapa ahli antara lain, salah satunya adalah menurut Fiedler (1967) mendefinisikan pemimpin dengan pengertian "seseorang yang berada dalam kelompok, sebagai pemberi tugas atau sebagai pengarah dan mengkoordinasikan kegiatan kelompok yang relevan, serta sebagai penanggung jawab utama".

Menurut University of lowa Studies yang dikutip Robbins dan Coulter (2002), Lewin menyimpulkan ada tiga gaya kepemimpinan, yaitu : gaya kepemimpinan Autokratis, Demokratis/Partisipatif, Kendali bebas Tipe-tipe Kepemimpinan Kepemimpinan disini dibedakan menjadi lima tipe, yaitu : Tipe Otokratik, Paternalistik, Kharismatik, Kendali Bebas, dan Demokratis.

Pemimpin yang ideal adalah pemimpin yang dapat memenuhi tuntutan-tuntutan sebagai berikut : Mempunya pandangan ke muka, merasakan dirinya sebagai milik para karyawan, pandangan hidup yang dianut tercermin pada pola dan tingkah lakunya, peka dan tanggap, tangkas berpikir dan bertindak, dapat membedakan hal yang prinsipal, bermusyawarah dan bertanggung jawab.

\section{Iklim Organisasi}

\section{Definisi Iklim Organisasi}

Menurut Stringer dalam Wirawan (2007) mendefinisikan bahwa iklim organisasi sebagai koleksi dan pola lingkungan yang menentukan munculnya motivasi serta berfokus pada persepsipersepsi yang masuk akal sehingga mempunyai pengaruh langsung terhadap kinerja anggota organisasi.

Aspek-aspek Iklim Organisasi

Menurut Stringer Wirawan (2007) menyebutkan bahwa ada beberapa dimensi yang mempengaruhi motivasi anggota 
organisasi, diantaranya yaitu :struktur, standar-standar, tanggung jawab, pengakuan, dukungan dan komitmen.

Menurut Model Pines (1982) iklim kerja dapat diukur melalui empat dimensi, yaitu : dimensi psikologikal, struktural, sosial dan birokratik.

\section{Kinerja Karyawan}

Definisi Kinerja

Menurut Mangkunegara, kinerja adalah hasil yang dicapai melalui serangkaian kegiatan dan tata cara tertentu dengan menggunakan sumber daya perusahaan untuk mencapai sasaran perusahaan yang ditetapkan.

Kinerja dipengaruhi oleh tiga faktor, yaitu faktor individual, psikologis dan organisasi.

\section{Kerangka Pemikiran}

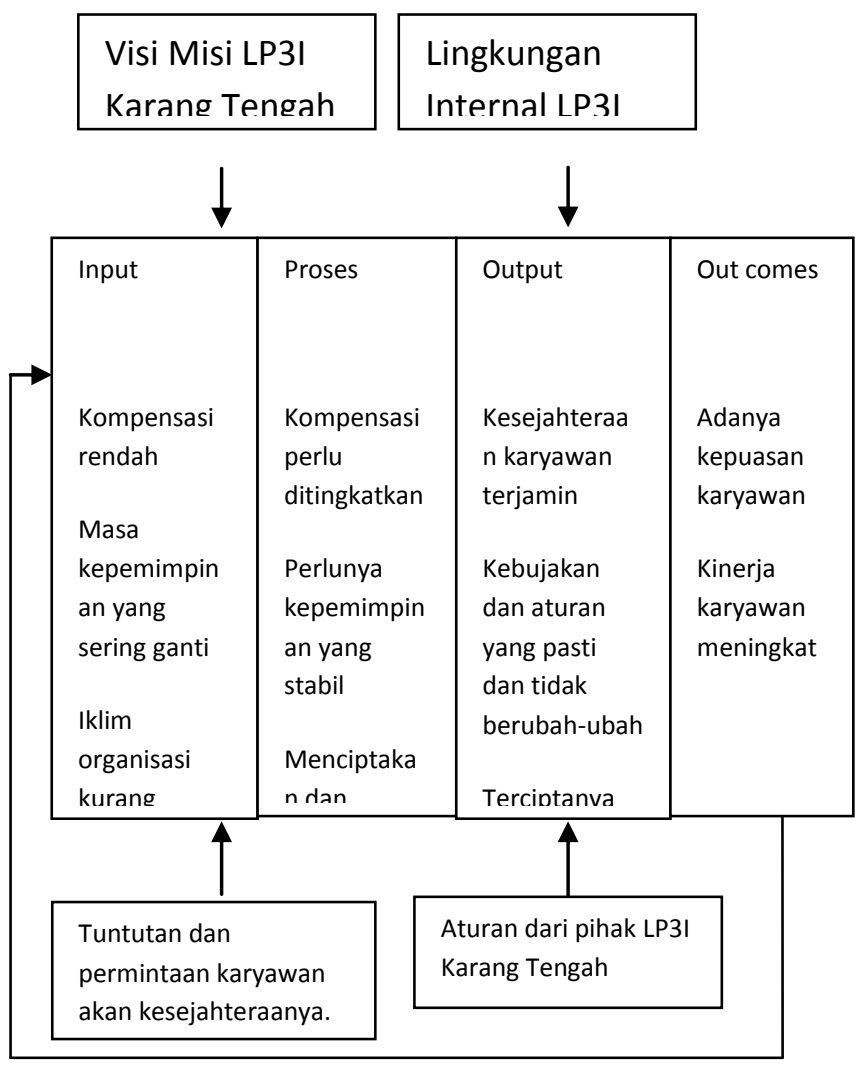

Berikut ini adalah gambar model penelitian :

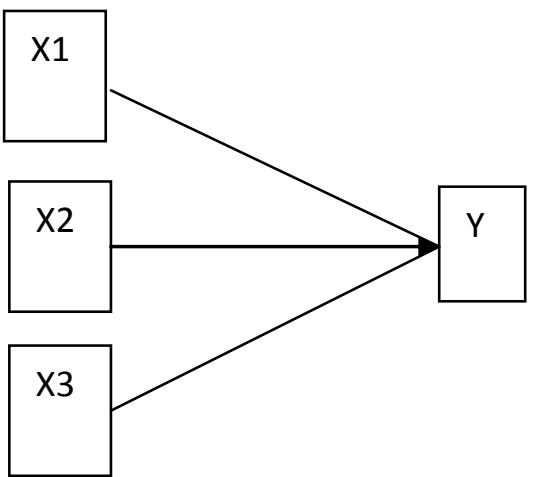

Keterangan :

$\mathrm{X} 1=$ kompensasi, $\mathrm{x} 2=$ gaya kepemimpinan, $\mathrm{x} 3=\mathrm{iklim}$ organisasi dan $\mathrm{Y}=$ kinerja karyawan.

\section{Hipotesis Penelitian}

Berdasarkan identifikasi masalah dan model penelitian yang disusun hipotesis penelitiannya adalah

Diduga terdapat pengaruh yang signifikan antara kompensasi terhadap kinerja karyawan LP3I kampus Karang Tengah

Diduga terdapat pengaruh yang signifikan antara gaya kepemimpinan terhadap kinerja karyawan LP3I kampus Karang Tengah

Diduga terdapat pengaruhyang signifikan antara iklim organisasi terhadap kinerja karyawan LP3I Kampus Karang Tengah.

Diduga terdapat pengaruh signifikan secara bersama-sama antara kompensasi, gaya kepemimpinan dan iklim organisasi terhadap kinerja karyawan LP3I Kampus Karang Tengah. 


\section{METODE PENELITIAN}

\section{Tempat dan Waktu Penelitian Tempat Penelitian}

Penelitian dilaksanakan di LP3I Kampus Karang Tengah, Ciledug, Tangerang.

\section{Waktu Penelitian}

Dalam penelitian ini dilakukan dari bulan Februari s/d Mei 2011.

\section{Metode Penelitian}

Penelitian ini merupakan penelitian kuantitatif, yaitu penelitian ilmiah yang sistematis dimana data bisa dikuantitatifkan. Sedangkan metodenya yaitu deskriptif analisis dengan menggunakan teknik survey. Metode survey deskriptif adalah suatu metode penelitian yang mengambil sampel dari suatu populasi dan menggunakan kuesioner sebagai alat pengumpul data. Kemudian hasilnya akan dipaparkan secara deskriptif dan pada akhir penelitian akan dianalisis untuk menguji hipotesis yang diajukan pada awal penelitian (Effendi, 2003).

\section{Variabel dan Instrumen}

\section{Variabel Penelitian}

Sugiyono (2006) mengatakan bahwa variabel merupakan pengukuran terhadap gejala yang menjadi fokus peneliti untuk diamati. Dalam penelitian ini, ada dua variabel yang digunakan yaitu variabel independen atau variabel bebas dan variabel dependen atau terikat.

Dalam hal ini, variabel bebasnya adalah kompensasi (x1), gaya kepemimpinan (x2) dan iklim organisasi (x3). Variabel terikatnya (Y) adalah kinerja karyawan LP3I Kampus Karang Tengah, Ciledug.

Instrumen Penelitian

Alat ukur penelitian ini berbentuk angket dengan tingkat pengukuran ordinal, kategori jawaban terdiri dari 5 tingkatan dengan tabel skala likert sebagai berikut :

\begin{tabular}{|l|l|}
\hline NILAI & JAWABAN \\
\hline 1 & $\begin{array}{l}\text { Sangat Tidak Setuju } \\
(\text { STS })\end{array}$ \\
\hline 2 & Tidak setuju (TS) \\
\hline 3 & Ragu-ragu (R) \\
\hline 4 & Setuju (S) \\
\hline 5 & Sangat setuju (SS) \\
\hline
\end{tabular}

Variabel Kompensasi (x1) Variabel Gaya Kepemimpinan (x2)

Variabel Iklim Organisasi (x3) Variabel Kinerja Karyawan (Y) Dimana masing-masing variabel dijelaskan definisi konseptualnya, definisi operasional dan kisi-kisi instrumennya.

\section{Populasi dan Sampel}

Menurut Sugiyono (2005) mengatakan bahwa populasi merupakan wilayah generalisasi yang terdiri dari objek atau subjek yang menjadi kuantitas dan karakteristik tertentu yang ditetapkan oleh peneliti untuk dipelajari dan kemudian ditarik kesimpulannya. Dalam penelitian ini, populasi yang akan diteliti adalah para karyawan LP3I Karang Tengah Ciledug.

Menurut Arikunto (1998) sampel adalah bagian dari populasi (sebagian atau wakil populasi yang diteliti). Dalam penelitian yang akan dilakukan, metode yang digunakan adalah sampel jenuh, yaitu bagian dari jumlah dan karakteristik yang dimiliki oleh populasi tersebut. Penulis mengambil populasi yaitu seluruh karyawan LP3I karang 
Tengah, Ciledug sebanyak 30 orang.

\section{Tehnik Pengumpulan data}

Data yang diperoleh melalui observasi secara langsung. Penulis terjun langsung ke lapangan dengan mengadakan observasi dan menyebarkan kuesioner langsung.

Data sekunder yaitu data yang dikumpulkan penulis dalam bentuk yang sudah jadi. Adapun sumber data dapat berupa internal data dan eksternal data.

\section{Teknik Analisis data}

Sebelum melakukan analisis terhadap indikator yang digunakan terlebih dahulu dilakukan uji instrumen, yaitu dengan uji validitas dan uji reliabilitas.

Sebelum melakukan analisis data, terlebih dahulu dipenuhi persyaratan analisis dengan uji normalitas, uji multikolinieritas, uji heteroskedastisitas dan uji regresi berganda.

\section{PEMBAHASAN}

\section{Pengujian Persyaratan Analisis}

\section{Uji Validitas}

Untuk mengolah uji validitas penulis menggunakan perhitungan statistik dengan Software IBM SPSS (Statistical Program for Social Science) versi 19.00 for windows diperoleh nilai $r$ hitung lebih besar dari $r_{\text {tabel }}$ dan nilai $r$ positif, maka butir pernyataan dikatakan valid. Nilai $r_{\text {tabel }}$ untuk 30 responden dengan taraf kesalahan 5\% sebesar 0,361 . Hasil uji validitas disajikan dalam tabel berikut :
Uji Validitas Variabel Kompensasi $\left(\mathbf{X}_{1}\right)$

\begin{tabular}{|l|l|l|l|}
\hline Kuesioner & $\begin{array}{l}\text { Nilai } \\
\text { hitung }\end{array}$ & $\begin{array}{l}\text { Nilai r } \\
\text { tabel }\end{array}$ & Keterangan \\
\hline 1 & 0.42 & 0.361 & Valid \\
\hline 2 & 0.698 & 0.361 & Valid \\
\hline 3 & 0.705 & 0.361 & Valid \\
\hline 4 & 0.692 & 0.361 & Valid \\
\hline 5 & 0.724 & 0.361 & Valid \\
\hline 6 & 0.783 & 0.361 & Valid \\
\hline 7 & 0.557 & 0.361 & Valid \\
\hline 8 & 0.616 & 0.361 & Valid \\
\hline 9 & 0.8 & 0.361 & Valid \\
\hline 10 & 0.775 & 0.361 & Valid \\
\hline 11 & 0.49 & 0.361 & Valid \\
\hline 12 & 0.701 & 0.361 & Valid \\
\hline Sumber & $:$ & Primer & yang telah \\
\hline
\end{tabular}

Sumber : Data Primer yang telah diolah.(2012)

\section{Uji Validitas Variabel Gaya \\ Kepemimpinan $\left(\mathbf{X}_{2}\right)$}

\begin{tabular}{|c|c|c|c|}
\hline Kuesioner & $\begin{array}{c}\text { Nilai r } \\
\text { hitung }\end{array}$ & $\begin{array}{c}\text { Nilai } \mathrm{r} \\
\text { tabel }\end{array}$ & Keterangan \\
\hline 1 & 0.744 & 0.361 & Valid \\
\hline 2 & 0.695 & 0.361 & Valid \\
\hline 3 & 0.728 & 0.361 & Valid \\
\hline 4 & 0.589 & 0.361 & Valid \\
\hline 5 & 0.729 & 0.361 & Valid \\
\hline 6 & 0.702 & 0.361 & Valid \\
\hline 7 & 0.862 & 0.361 & Valid \\
\hline 8 & 0.755 & 0.361 & Valid \\
\hline 9 & 0.408 & 0.361 & Valid \\
\hline
\end{tabular}




\begin{tabular}{|c|c|c|c|}
\hline 10 & 0.437 & 0.361 & Valid \\
\hline 11 & 0.418 & 0.361 & Valid \\
\hline 12 & 0.641 & 0.361 & Valid \\
\hline 13 & 0.804 & 0.361 & Valid \\
\hline 14 & 0.739 & 0.361 & Valid \\
\hline 15 & 0.885 & 0.361 & Valid \\
\hline 16 & 0.777 & 0.361 & Valid \\
\hline 17 & 0.775 & 0.361 & Valid \\
\hline 18 & 0.775 & 0.361 & Valid \\
\hline 19 & 0.784 & 0.361 & Valid \\
\hline 20 & 0.657 & 0.361 & Valid \\
\hline
\end{tabular}

Sumber : Data Primer yang telah diolah.(2012)

\begin{tabular}{|l|l|l|l|}
\hline 2 & 0.658 & 0.361 & Valid \\
\hline 3 & 0.704 & 0.361 & Valid \\
\hline 4 & 0.739 & 0.361 & Valid \\
\hline 5 & 0.784 & 0.361 & Valid \\
\hline 6 & 0.772 & 0.361 & Valid \\
\hline 7 & 0.506 & 0.361 & Valid \\
\hline
\end{tabular}

Sumber : Data Primer yang telah diolah.(2012)

\section{Uji Realiabilitas}

Untuk mengolah uji reliabilitas maka digunakan Software IBM SPSS (Statistical Program for Social Science) versi 19.00 for windows. Jika nilai Cronbach Alpha > lebih besar dari $r_{\text {tabel }}$ dan nilai $r$ positif, maka butir pernyataan dikatakan reliabel. Adapun nilai $r_{\text {tabel }}$ (uji dua sisi) untuk 30 responden dengan taraf kesalahan 5\% sebesar 0,361 .

Adapun hasil uji reliabilitas untuk semua variabel dalam penelitian ini dapat dilihat seperti tabel berikut :

\section{Uji Reliabilitas}

\begin{tabular}{|l|l|l|l|l|}
\hline $\begin{array}{l}\mathrm{N} \\
\mathrm{o}\end{array}$ & $\begin{array}{l}\text { Variab } \\
\text { el }\end{array}$ & $\begin{array}{l}\text { Cronba } \\
\text { ch } \\
\text { Alpha }\end{array}$ & $\begin{array}{l}\text { Nilai } \\
\mathrm{r} \\
\text { tabel }\end{array}$ & Ket \\
\hline 2 & $\begin{array}{l}\text { Komp } \\
\text { ensasi }\end{array}$ & 0,884 & $\begin{array}{l}0,36 \\
1\end{array}$ & $\begin{array}{l}\text { Relia } \\
\text { bel } \\
\text { nan } \\
\text { nepe }\end{array}$ \\
\hline 3 & $\begin{array}{l}\text { Iklim } \\
\text { Organi } \\
\text { sasi }\end{array}$ & 0,707 & 0,36 & $\begin{array}{l}\text { Relia } \\
\text { bel }\end{array}$ \\
\hline 4 & $\begin{array}{l}\text { Kinerj } \\
\text { a }\end{array}$ & 0,797 & $\begin{array}{l}0,36 \\
1\end{array}$ & $\begin{array}{l}\text { Relia } \\
\text { bel }\end{array}$ \\
\hline
\end{tabular}

Sumber: Data Primer yang telah diolah 
Untuk lebih jelas hasil olahan dengan menggunakan Software IBM SPSS (Statistical Program for Social Science) versi 19.00 for windows bisa dilihat pada lampiran, pada correlation diperoleh nilai $r_{\text {hitung }}$ lebih besar dari $r_{\text {tabel }}$ dan nilai $r$ positif, maka butir pernyataan dikatakan reliabel.

\section{Uji Asumsi Klasik}

\section{Uji Multikolinieritas}

Pengujian ada tidaknya gejala multikolinearitas dilakukan dengan memperhatikan nilai matriks korelasi yang dihasilkan pada saat pengolahan data serta nila VIF (Variance Inflation Factor) dan Tolerance-nya sebagai berikut:

Jika nilai tolerance tidak mendekati angka 1 dan nilai VIF diatas 10 , maka model regresi tersebut terdapat problem multikolinearitas.

Jika nilai tolerance mendekati angka 1 dan nilai VIF dibawah 10, maka model regresi tersebut tidak terdapat problem multikolinearitas (Santoso,2003).

Hasil Uji Multikolinieritas dapat dilihat pada tabel dibawah ini :

\section{Hasil Uji Multikolinieritas}

Coefficients $^{\text {a }}$

\begin{tabular}{|c|c|c|c|c|c|c|c|}
\hline \multirow[b]{2}{*}{ Model } & \multicolumn{2}{|c|}{$\begin{array}{l}\text { Unstanda } \\
\text { rdized } \\
\text { Coefficie } \\
\text { nts }\end{array}$} & \multicolumn{2}{|l|}{\begin{tabular}{|l|} 
Standar \\
dized \\
Coeffici \\
ents
\end{tabular}} & \multirow[b]{2}{*}{$\begin{array}{l}\mathrm{Si} \\
\text { g. }\end{array}$} & \multicolumn{2}{|c|}{$\begin{array}{l}\text { Collineari } \\
\text { ty } \\
\text { Statistics }\end{array}$} \\
\hline & B & $\begin{array}{l}\text { Std. } \\
\text { Err } \\
\text { or }\end{array}$ & Beta & $\mathrm{T}$ & & $\begin{array}{l}\text { Toler } \\
\text { ance }\end{array}$ & $\begin{array}{l}\text { VI } \\
\text { F }\end{array}$ \\
\hline $\begin{array}{c}1 \text { (Cons } \\
\operatorname{tant})\end{array}$ & $\begin{array}{l}3.23 \\
3\end{array}$ & $\begin{array}{l}.56 \\
6\end{array}$ & & $\begin{array}{l}5.7 \\
13\end{array}$ & $\begin{array}{l}.0 \\
00\end{array}$ & & \\
\hline $\mathrm{X} 1$ & .172 & $\begin{array}{l}.17 \\
6\end{array}$ & .269 & $\begin{array}{l}2.9 \\
77\end{array}$ & 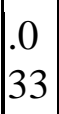 & .453 & $\begin{array}{l}2.2 \\
09\end{array}$ \\
\hline $\mathrm{X} 2$ & .240 & $\begin{array}{l}.18 \\
1\end{array}$ & .385 & $\begin{array}{l}2.3 \\
25\end{array}$ & $\begin{array}{l}.0 \\
19\end{array}$ & .406 & $\begin{array}{l}2.4 \\
63\end{array}$ \\
\hline
\end{tabular}

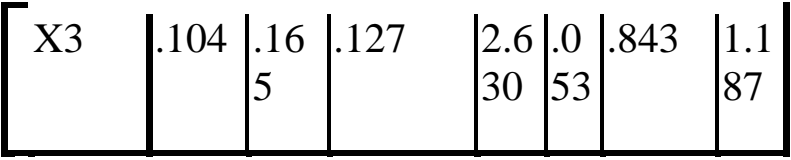

a. Dependent Variable: Y

Sumber : Data Primer yang telah diolah dengan IBM SPSS versi 19.

Dari data tabel diatas dapat diketahui bahwa syarat untuk lolos dari uji multikolinearitas sudah terpenuhi oleh seluruh variabel independen yang ada, yaitu nilai tolerance yang tidak kurang dari 0,10 dan nilai VIF (Variance Inflation Factor) yang tidak lebih dari 10. Maka dari itu dapat disimpulkan bahwa seluruh variabel independen yang digunakan dalam penelitian ini tidak berkorelasi antara variabel independen satu dengan variabel independen lainnya.

\section{Uji Heteroskedastisitas}

Menurut Ghozali (2006), uji heteroskedastisitas bertujuan untuk menguji apakah dalam sebuah model regresi terjadi ketidaksamaan varians dari residual dari satu pengamatan satu ke pengamatan yang lain. Jika varians dari residu atau dari satu pengamatan ke pengamatan yang lain tetap, maka disebut homokedastisitas. Dan jika varians berbeda maka disebut heteroskedastisitas. Model regresi yang baik adalah yang homokedastisitas atau tidak terjadi heteroskedastisitas.

Heteroskedastisitas adalah suatu keadaan di mana masing-masing kesalahan pengganggu mempunyai varian yang berlainan. Heteroskedastisitas diuji dengan menggunakan uji koefisien korelasi Rank Spearman yaitu mengkorelasikan antara absolut residual hasil regresi dengan semua variabel bebas. Bila signifikansi hasil korelasi lebih kecil dari $0,05(5 \%)$ maka persamaan regresi tersebut 
heteroskedastisitas dan sebaliknya berarti non heteroskedastisitas atau homoskedastisitas. Heteroskedastisitas diuji dengan menggunakan uji koefisien korelasi Rank Spearman yaitu mengkorelasikan antara absolut residual hasil regresi dengan semua variabel bebas.

\section{Hasil Uji Heterokedastisitas}

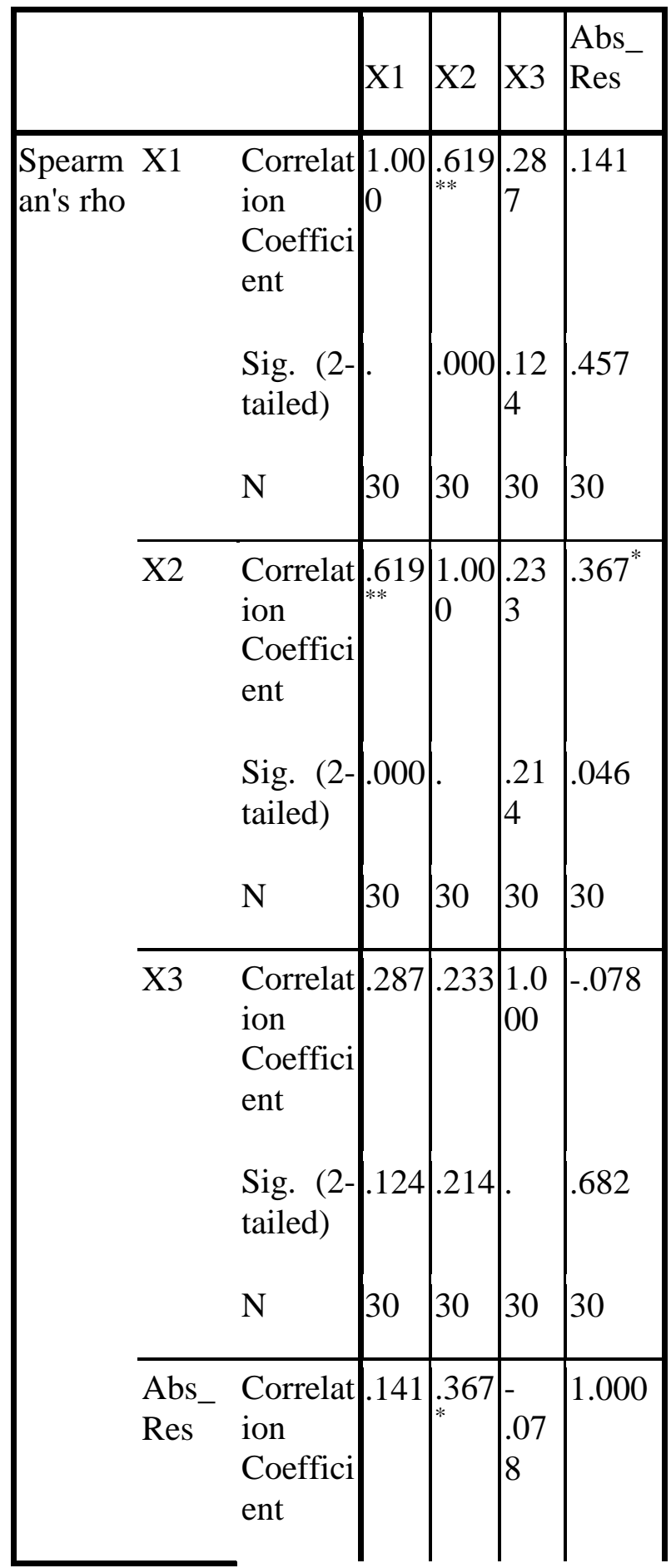

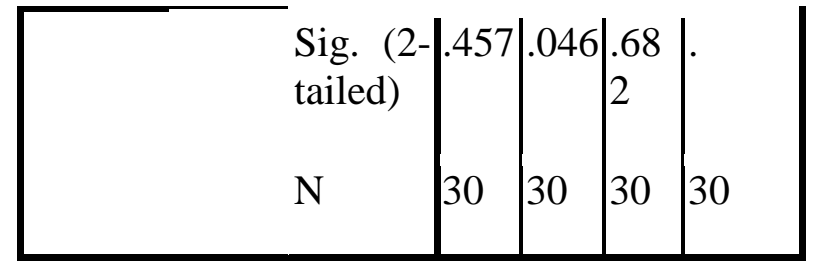

Sumber : Data Primer yang telah diolah dengan IBM SPSS versi 19 (2012).

Hasil output SPSS diperoleh interpretasi (pada baris terakhir atau kolom terakhir)

\section{Heteroskedastisitas}

\begin{tabular}{|c|c|c|c|}
\hline $\begin{array}{l}\text { Variabel } \\
\text { Bebas }\end{array}$ & $\mathrm{R}$ & sig & Keterangan \\
\hline $\begin{array}{l}\text { Kompensa } \\
\text { si }\left(X_{1}\right) \\
\text { Gaya } \\
\text { Kepemimp } \\
\text { inan }\left(X_{2}\right) \\
\text { Iklim } \\
\text { Organisasi } \\
\left(X_{3}\right)\end{array}$ & $\begin{array}{l}- \\
0,1 \\
41 \\
- \\
0,3 \\
67 \\
- \\
0,0 \\
78\end{array}$ & $\begin{array}{l}0,4 \\
57 \\
0,4 \\
60 \\
0,6 \\
82\end{array}$ & $\begin{array}{l}\text { Homokedast } \\
\text { isitas } \\
\text { Homokedast } \\
\text { isitas } \\
\text { Homokedast } \\
\text { isitas }\end{array}$ \\
\hline
\end{tabular}

Sumber : Data Primer yang telah diolah.

Dari tabel di atas menunjukkan bahwa variabel yang diuji tidak mengandung homoskedastisitas. Artinya tidak ada korelasi antara besarnya data dengan residual sehingga bila data diperbesar tidak menyebabkan residual (kesalahan) semakin besar pula.

\section{Uji Normalitas}

Uji normalitas data bertujuan untuk menguji apakah dalam model regresi, variabel residual memiliki distribusi normal (Gozali,2006). Uji normalitas bertujuan untuk menguji apakah dalam model regresi, variabel dependen dan independen keduanya mempunyai distribusi normal atau tidak. Uji normalitas menggunakan uji Kolmogorov-Smirnov, dengan uji ini 
dapat diketahui data yang digunakan berdistribusi normal atau tidak. Apabila Sign $\mathrm{t}$ hitung >0.05, maka data tersebut berdistribusi normal dan begitu juga sebaliknya (Santoso, 2001).

\section{Hasil Uji Normalitas Data}

One-Sample Kolmogorov-Smirnov Test

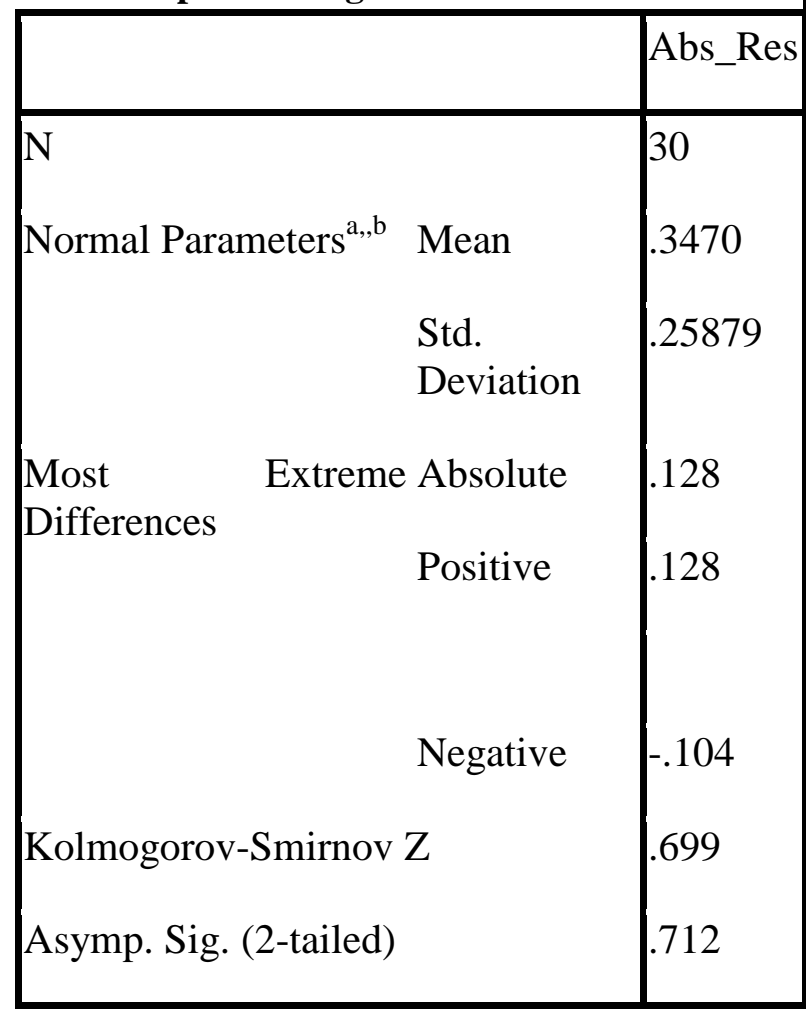

Sumber : Data Primer yang telah diolah
Dari hasil pengujian diatas diperoleh nilai signifikansi sebesar $0.712>0,05$ Maka asumsi normalitas terpenuhi.

\section{Uji Regresi Berganda}

Regresi Berganda digunakan untuk mengetahui seberapa besar pengaruh dari variabel bebas (pemasaran on-line, harga, dan pelayanan) secara bersama-sama terhadap variabel terikat (keputusan pembelian). Sehingga dapat diketahui apakah ketiga variabel bebas tersebut berpengaruh positif atau negatif terhadap keputusan pembelian produk pada website www.pagarkanopi.com.

Berdasarkan perhitungan regresi berganda menggunakan program IBM SPSS (Statistical Program for Social Science) versi 19.00 for windows, diperoleh hasil sebagai berikut :

\section{Tabel 4.13. Hasil Uji Regresi Berganda}

Sumber : Data Primer yang telah diolah dengan IBM SPSS versi 19 (2012)

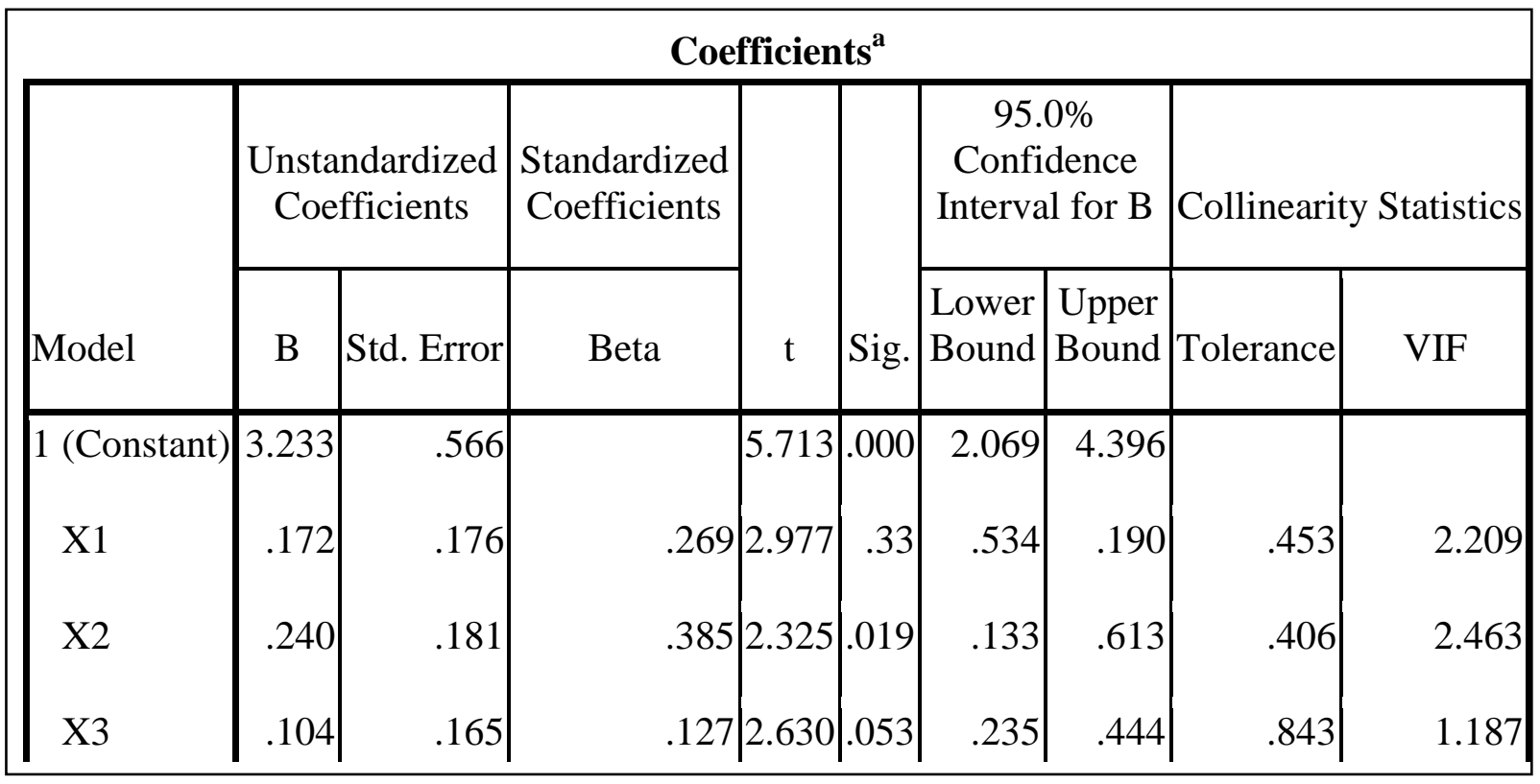


Dari hasil perhitungan pada tabel diatas dapat disajikan ke dalam bentuk persamaan regresi standardized sebagai berikut :

$Y=3.233+0,172 X_{1}+0,240 X_{2}+0,104 X_{3}$
2. Variabel kompensasi $\left(\mathrm{X}_{1}\right)$ berpengaruh positif terhadap kinerja karyawan (Y) dengan nilai koefisien sebesar 0,172. Yang artinya jika variabel kompensasi $\left(\mathrm{X}_{1}\right)$ meningkat satu satuan dengan

Tabel 4.14. Hasil Uji Determinasi

\begin{tabular}{|c|c|c|c|c|c|c|c|c|c|}
\hline \multirow[b]{2}{*}{ Model } & \multirow[b]{2}{*}{$\mathrm{R}$} & \multirow[b]{2}{*}{$\begin{array}{c}\mathrm{R} \\
\text { Square }\end{array}$} & \multirow[b]{2}{*}{$\begin{array}{l}\text { Adjusted } \\
\text { R Square }\end{array}$} & \multirow{2}{*}{$\begin{array}{l}\text { Std. Error } \\
\text { of the } \\
\text { Estimate }\end{array}$} & \multicolumn{5}{|c|}{ Change Statistics } \\
\hline & & & & & $\begin{array}{c}\text { R Square } \\
\text { Change }\end{array}$ & $\begin{array}{c}\mathrm{F} \\
\text { Change }\end{array}$ & df1 & df2 & $\begin{array}{c}\text { Sig. F } \\
\text { Change }\end{array}$ \\
\hline 1 & $.044^{\mathrm{a}}$ & .002 & .034 & .47073 & .002 & .055 & 1 & 28 & .816 \\
\hline
\end{tabular}

a. Predictors: (Constant), X1

b. Dependent Variable: Y

Sumber : Data Primer yang telah diolah dengan IBM SPSS versi 19 (2012).

Keterangan:

$\mathrm{Y} \quad=$ Kinerja Karyawan

$\mathrm{X} 1=$ Variabel Kompensasi

X2 = Variabel Gaya Kepemimpinan

X3 = Variabel Iklim Organisasi

Hasil persamaan regresi berganda tersebut dapat dilihat bahwa koefisien regresi yang diperoleh bertanda positif. Hal tersebut menunjukkan bahwa variabel kompensasi, gaya kepemimpinan dan iklim organisasi mempunyai pengaruh positif terhadap kinerja karyawan, artinya setiap ada peningkatan variabel kompensasi, gaya kepemimpinan dan iklim organisasi akan meningkatkan pula kinerja karyawan di LP3I Karang Tengah, Ciledug.

Adapun persamaan tersebut dapat dijelaskan sebagai berikut :

1. Konstanta sebesar 3.233, menyatakan bahwa tanpa variabel kompensasi, gaya kepemimpinan dan iklim organisasi besarnya nilai kinerja karyawan tetap terbentuk sebesar 3.233. asumsi variabel gaya kepemimpinan $\left(\mathrm{X}_{2}\right)$ dan variabel iklim organisasi $\left(\mathrm{X}_{3}\right)$ tetap, maka kinerja karyawan akan meningkat sebesar 0,172.

3. Variabel gaya kepemimpinan $\left(\mathrm{X}_{2}\right)$ berpengaruh positif terhadap kinerja karyawan $(\mathrm{Y})$ dengan nilai koefisien sebesar 0,240. Yang artinya jika variabel gaya kepemimpinan $\left(\mathrm{X}_{2}\right)$ meningkat satu satuan dengan asumsi variabel kompensasi $\left(\mathrm{X}_{1}\right)$ dan variabel iklim organisasi $\left(\mathrm{X}_{3}\right)$ tetap, maka kinerja karyawan (Y) akan meningkat sebesar 0,240.

4. Variabel iklim organisasi $\left(\mathrm{X}_{3}\right)$ berpengaruh positif terhadap kinerja karyawan (Y) dengan nilai koefisien sebesar 0,104. Yang artinya jika variabel iklim organisasi $\left(\mathrm{X}_{3}\right)$ meningkat satu satuan dengan asumsi variabel kompensasi $\left(\mathrm{X}_{1}\right)$ dan variabel gaya kepemimpinan $\left(\mathrm{X}_{2}\right)$ tetap, maka kinerja karyawan (Y) akan meningkat sebesar 0,104. 


\section{a. Koefisien Determinasi}

Untuk mengetahui kontribusi besarnya pengaruh variabel kompensasi, gaya kepemimpinan, dan iklim organisasi secara parsial ataupun secara bersama-sama terhadap kinerja karyawan di LP3I Karang Tengah, Ciledug. Dapat dijelasakan sebagai berikut:

1. Untuk mengetahui besarnya pengaruh kompensasi terhadap kinerja karyawan di LP3I Karang Tengah. Dapat dilihat pada tabel dibawah ini:
Dari tabel diatas dapat dilihat bahwa nilai R Square sebesar 0,002 atau $2 \%$. Hal ini menunjukkan bahwa pengaruh kompensasi terhadap kinerja karyawan di LP3I Karang Tengah, Ciledug sebesar $2 \%$.

2. Untuk mengetahui besarnya pengaruh gaya kepemimpinan terhadap kinerja karyawan di LP3I Karang Tengah, Ciledug. Dapat dilihat pada tabel dibawah ini :

Tabel 4.15. Hasil Uji Determinasi

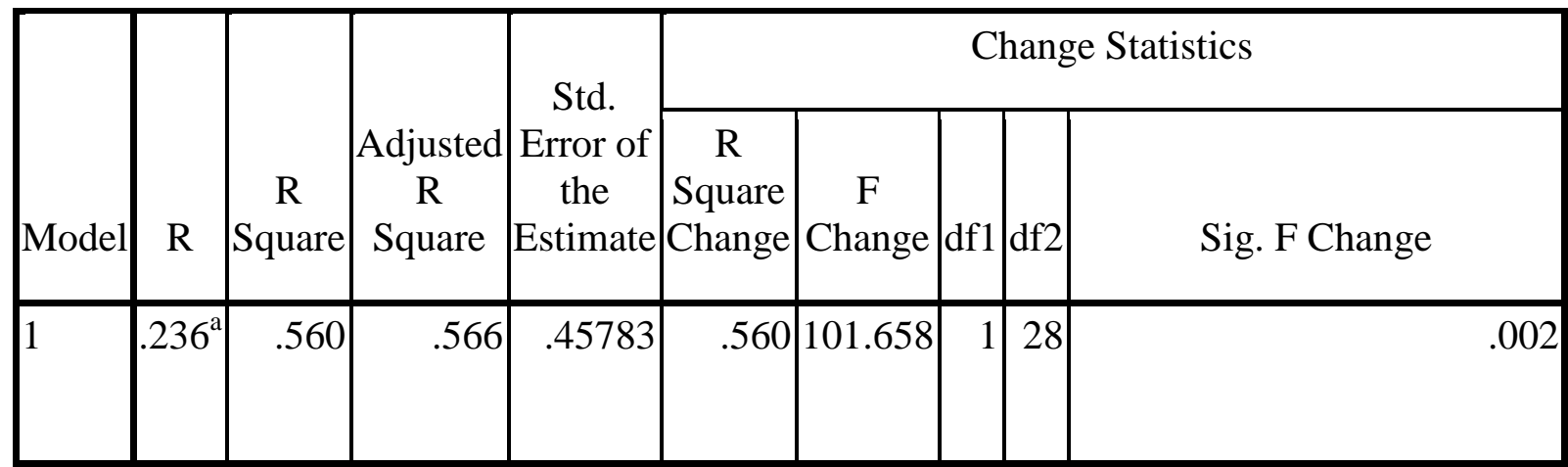

a. Predictors: (Constant), X2

Sumber : Data Primer yang telah diolah dengan IBM SPSS versi 19 (2012).

Dari tabel diatas dapat dilihat bahwa nilai R Square sebesar 0,560 atau 56\%. Hal ini menunjukkan bahwa pengaruh gaya kepemimpinan terhadap kinerja karyawan b. Dependent Variable: Y

di LP3I Karang Tengah, Ciledug sebesar $56 \%$.

3. Untuk mengetahui besarnya pengaruh iklim organisasi terhadap kinerja karyawan di LP3I Karang Tengah, Ciledug. Dapat dilihat pada tabel dibawah ini :

Tabel 4.16. Hasil Uji Determinasi

\begin{tabular}{|c|c|c|c|c|c|c|c|c|c|}
\hline \multirow[b]{2}{*}{ Model } & \multirow[b]{2}{*}{$\mathrm{R}$} & \multirow[b]{2}{*}{$\begin{array}{c}\mathrm{R} \\
\text { Square }\end{array}$} & \multirow[b]{2}{*}{$\begin{array}{l}\text { Adjusted R } \\
\text { Square }\end{array}$} & \multirow[b]{2}{*}{$\begin{array}{l}\text { Std. Error of the } \\
\text { Estimate }\end{array}$} & \multicolumn{5}{|c|}{ Change Statistics } \\
\hline & & & & & $\begin{array}{l}\text { R Square } \\
\text { Change }\end{array}$ & $\begin{array}{c}\mathrm{F} \\
\text { Change }\end{array}$ & df1 & df2 & $\begin{array}{l}\text { Sig. F } \\
\text { Change }\end{array}$ \\
\hline 1 & $215^{\mathrm{a}}$ & .046 & .012 & .46016 & & 1.358 & 1 & 28 & .254 \\
\hline
\end{tabular}

Sumber : Data Primer yang telah diolah dengan IBM SPSS versi $19 \quad(201$ 
Tabel 4.17. Hasil Uji Determinasi

\begin{tabular}{|l|l|l|l|l|l|l|l|l|l|l|}
\hline & R & \multicolumn{2}{|c|}{ R Square } & Adjusted R Square & \multicolumn{2}{c|}{$\begin{array}{c}\text { Std. Error of the } \\
\text { Estimate }\end{array}$} & Change Statistics \\
\hline & & & & & R Square Change & F Change & df1 & df2 & Sig. F Change \\
\hline 1 & $.327^{\text {a }}$ & .701 & .489 & .46218 & .701 & 48.754 & 3 & 26 & .003 \\
\hline
\end{tabular}

a. Predictors: (Constant), X3, X1, X2

Sumber : Data Primer yang telah diolah dengan IBM SPSS versi 19 (2012).

Dari tabel diatas dapat dilihat bahwa nilai $\mathrm{R}$ Square sebesar 0,701 atau $70,1 \%$. Hal ini menunjukkan bahwa kompensasi, gaya kepemimpinan dan iklim organisasi secara bersama-sama berpengaruh terhadap kinerja karyawan di LP3I Karang Tengah, Ciledug sebesar 70,1\%. Sisanya 29,9\% dipengaruhi oleh faktor lain yang tidak diteliti.

\section{A. Uji hipotesis}

\section{Uji Parsial (Uji t)}

Untuk menguji pengaruh kompensasi, gaya kepemimpinan, dan iklim organisasi secara parsial terhadap kinerja karyawan di LP3I Karang Tengah, Ciledug dapat digunakan dengan uji Statistik t (uji t). Dengan menggunakan taraf signifikansi 5\% $(0,05)$ dan derajat kebebasan (dk) dengan rumus : $\mathrm{dk}=\mathrm{n}-\mathrm{k}$ 1, dimana $n$ adalah jumlah responden dan $k$ adalah jumlah variabel yang diteliti.

\begin{tabular}{|c|c|c|c|c|c|c|c|c|c|c|}
\hline \multirow{2}{*}{ Model } & \multicolumn{2}{|c|}{$\begin{array}{l}\text { Unstandardized } \\
\text { Coefficients }\end{array}$} & \multirow[t]{2}{*}{$\begin{array}{c}\text { Standardized } \\
\text { Coefficients }\end{array}$} & \multirow{2}{*}{$\mathrm{t}$} & \multirow{2}{*}{ Sig. } & \multicolumn{2}{|c|}{$\begin{array}{c}95.0 \% \\
\text { Confidence } \\
\text { Interval for B }\end{array}$} & \multicolumn{3}{|c|}{ Correlations } \\
\hline & B & $\begin{array}{l}\text { Std. } \\
\text { Error }\end{array}$ & & & & $\begin{array}{l}\text { Lower } \\
\text { Bound }\end{array}$ & $\begin{array}{l}\text { Upper } \\
\text { Bound }\end{array}$ & $\begin{array}{l}\text { Zero- } \\
\text { order }\end{array}$ & Partial & Part \\
\hline (Constant) & 3.233 & .566 & & 5.713 & .000 & 2.069 & 4.396 & & & \\
\hline $\mathrm{X} 1$ & .172 & .176 & .269 & 2.977 & .033 & .534 & .190 & .044 & .188 & .181 \\
\hline $\mathrm{X} 2$ & .240 & .181 & .385 & 2.325 & .019 & .133 & .613 & .236 & .251 & .246 \\
\hline
\end{tabular}

Kemudian membandingkan $\mathrm{t}_{\text {hitung }}$ dengan $\mathrm{t}_{\text {tabel }}$ dengan kriteria :

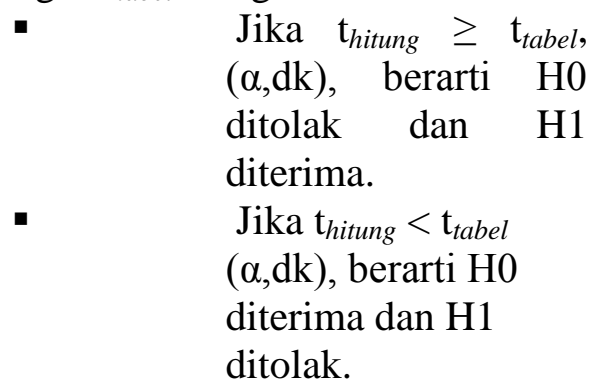
adalah :

Dimana derajat kebebasan (dk)

$$
\begin{aligned}
\mathrm{dk} & =\mathrm{n}-\mathrm{k}-1 \\
& =30-3-1 \\
& =26 \\
\mathrm{t}_{\text {tabel }} & =\mathrm{t}(\alpha ; \mathrm{dk}) \\
& =(0,05 ; 26) \\
& =2,0555 \rightarrow \text { liat tabel }
\end{aligned}
$$
pengolahan IBM SPSS versi 19 for window dapat dilihat pada tabel dibawah ini :
Adapun hasil uji t dengan 
1. Pengujian Hipotesis I dengan Uji Parsial (uji t)

$\mathrm{H} 0: \mathrm{b}_{1}=0$ Tidak ada pengaruh positif dan signifikan variabel kompenasi terhadap kinerja karyawan di LP3I Karang Tengah, Ciledug.

$\mathrm{H} 1: \mathrm{b}_{1} \neq 0$ Ada pengaruh positif dan signifikan variabel kompensasi terhadap kinerja karyawan di LP3I Karang Tengah, Ciledug.

Dari tabel diatas dapat dilihat bahwa variabel variabel kompensasi diperoleh $\mathrm{t}_{\text {hitung }} 2.977$ dengan signifikansi t sebesar 0,033 lebih besar dari $\mathrm{t}_{\text {tabel }}=2,0555$ $(2.977>2,0555)$, atau signifikansi $t$ lebih kecil dari $0,05 \quad(0,033<0,05)$, sesuai dengan kriteria yaitu: Jika $t_{\text {hitung }}$ $\geq \mathrm{t}_{\text {tabel }},(\alpha, \mathrm{dk})$, atau signifikansi $\mathrm{t}$ lebih kecil dari 0,05, berarti $\mathbf{H}_{\mathbf{0}}$ ditolak dan $\mathbf{H}_{2}$ diterima, hal ini menunjukkan bahwa Variabel kompensasi berpengaruh positif dan signifikan terhadap kinerja karyawan di LP3I Karang Tengah, Ciledug.

\section{Pengujian Hipotesis II dengan Uji Parsial (uji t)}

$\mathrm{H} 0: \mathrm{b}_{2}=0$ Tidak ada pengaruh positif dan signifikan variabel gaya kepemimpinan terhadap kinerja karyawan di LP3I Karang Tengah, Ciledug.

$\mathrm{H} 2: \mathrm{b}_{2} \neq 0$ Ada pengaruh positif dan signifikan variabel Gaya Kepemimpinan terhadap Kinerja karyawan di LP3I Karang Tengah, Ciledug.
Dari tabel diatas dapat dilihat bahwa variabel variabel harga diperoleh $\mathrm{t}_{\text {hitung }}$ $.2,325$ dengan signifikansi $\mathrm{t}$ sebesar 0,019 lebih besar dari $\mathrm{t}_{\text {tabel }}=2,0555$ $(2,325>2,0555)$, atau signifikansi $\mathrm{t}$ lebih kecil dari $0,05 \quad(0,019<0,05)$, sesuai dengan kriteria yaitu: $\mathrm{Jika}_{\mathrm{t}_{\text {hitung }}}$ $\geq \mathrm{t}_{\text {tabel }},(\alpha, \mathrm{dk})$, atau signifikansi $\mathrm{t}$ lebih kecil dari 0,05, berarti H0 ditolak dan H2 diterima, hal ini menunjukkan bahwa Variabel gaya kepemimpinan berpengaruh positif dan signifikan terhadap Kinerja karyawan di LP3I Karang Tengah, Ciledug.

\section{Pengujian Hipotesis III dengan Uji Parsial (uji t)}

$\mathrm{H} 0: \mathrm{b}_{3}=0$ Tidak ada pengaruh positif dan signifikan variabel Iklim Organisasi terhadap Kinerja karyawan di LP3I Karang Tengah, Ciledug.

$\mathrm{H} 3: \mathrm{b}_{3} \neq 0$ Ada pengaruh positif dan signifikan variabel Iklim Organisasi terhadap Kinerja karyawan di LP3I Karang Tengah, Ciledug.

Dari tabel diatas dapat dilihat bahwa variabel Pelayanan diperoleh $\mathrm{t}_{\text {hitung }}$ 2,630 dengan signifikansi t sebesar 0,034 lebih besar dari $\mathrm{t}_{\text {tabel }}=2,0555(2,630>$ $2,0555)$, atau signifikansi t lebih kecil dari $0,05(0,034<0,05)$, sesuai dengan kriteria yaitu: Jika $t_{\text {hitung }} \geq \mathrm{t}_{\text {tabel }},(\alpha, \mathrm{dk})$, atau signifikansi t lebih kecil dari 0,05, berarti H0 ditolak dan H3 diterima, hal ini menunjukkan bahwa Variabel Iklim organisasi berpengaruh positif dan signifikan terhadap Kinerja karyawan di LP3I Karang Tengah, Ciledug.

\section{Uji Simultan (Uji F)}


Untuk menguji pengaruh kompensasi, gaya kepemimpinan, dan iklim organisasi secara bersama-sama terhadap keputusan kinerja karyawan di LP3I Karang Tengah, Ciledug dapat digunakan dengan uji Statistik F (uji F). Dengan menggunakan taraf signifikansi $5 \%(0,05)$ dan derajat kebebasan (dk) dengan rumus : $\mathrm{dk}=\mathrm{n}-\mathrm{k}-1$, dimana $n$ adalah jumlah responden dan $k$ adalah jumlah variabel yang diteliti. Kemudian membandingkan $\mathrm{F}_{\text {hitung }}$ dengan $\mathrm{F}_{\text {tabel }}$ dengan kriteria :

Jika $\mathrm{F}_{\text {hitung }} \geq \mathrm{F}_{\text {tabel }}$,
$(\alpha, \mathrm{dk})$, berarti $\mathrm{H} 0$
ditolak dan
H1,H2,H3 diterima.
Jika $\mathrm{F}_{\text {hitung }}<\mathrm{F}_{\text {tabel }}$
$(\alpha, \mathrm{dk})$, berarti $\mathrm{H} 0$
diterima dan
H1,H2.H3 ditolak.

Dimana derajat kebebasan (dk) adalah :

$$
\begin{aligned}
\mathrm{dk} & =\mathrm{n}-\mathrm{k}-1 \\
= & 30-3-1 \\
= & 26 \\
\mathrm{~F}_{\text {tabel }}= & \mathrm{F}(\alpha ; \mathrm{dk}) \\
= & (0,05 ; 26) \\
= & 3,33
\end{aligned}
$$

Adapun hasil uji $\mathrm{F}$ dengan pengolahan IBM SPSS versi 19 for window (2012) dapat dilihat pada tabel dibawah ini

Tabel 4.21 ANOVA ${ }^{b}$

\begin{tabular}{|l|r|r|r|l|l|}
\hline Model & $\begin{array}{r}\text { Sum of } \\
\text { Squares }\end{array}$ & df & $\begin{array}{c}\text { Mean } \\
\text { Square }\end{array}$ & F & Sig. \\
\hline 1 Regression & .663 & 3 & .221 & 10.034 & $.039^{\mathrm{a}}$ \\
Residual & 5.554 & 26 & .214 & & \\
Total & 6.217 & 29 & & & \\
\hline
\end{tabular}

Sumber : Data Primer yang telah diolah dengan IBM SPSS versi 19 (2012).

\section{Uji Hipotesis IV dengan uji Simultan (Uji F)$$
\mathrm{H} 0: \mathrm{b}_{1}: \mathrm{b}_{2}: \mathrm{b}_{3}=0
$$

Tidak ada pengaruh positif dan signifikan variabel kompensasi, gaya kepemimpinan dan iklim organisasi secara bersama-sama terhadap Kinerja karyawan di LP3I Karang Tengah, Ciledug.

$$
\mathrm{H} 4: \mathrm{b}_{1}: \mathrm{b}_{2}: \mathrm{b}_{3} \neq 0
$$

Ada pengaruh positif dan signifikan variabel kompensasi, gaya kepemimpinan dan iklim organisasi secara bersama-sama terhadap Kinerja karyawan di LP3I Karang Tengah, Ciledug.

Dari hasil uji anova pada tabel diatas diperoleh $\mathrm{F}_{\text {hitung }}$ 10,034 dengan signifikansi $\mathrm{F}$ sebesar 0,039 lebih besar dari $\mathrm{F}_{\text {tabel }}=3,33(10,034$ $>3,33)$, atau signifikansi $F$ lebih kecil dari $0,05(0,039<0,05)$, sesuai dengan kriteria yaitu: Jika $\mathrm{F}_{\text {hitung }} \geq \mathrm{F}_{\text {tabel }}, \quad(\alpha, \mathrm{dk}), \quad$ atau signifikansi $\mathrm{F}<0,05$, berarti $\mathbf{H 0}$ ditolak dan $\mathrm{H4}$ diterima, hal ini menunjukkan bahwa Variabel Kompenasi, Gaya Kepemimpinan dan Iklim Organisasi secara bersama-sama berpengaruh positif dan siginifikan terhadap Kinerja karyawan di LP3I Karang Tengah, Ciledug.

\section{B. Pembahasan}

Dari hasil pengujian hipotesis statistik dan analisis di atas, maka sesuai dengan maksud dalam tujuan dalam penelitian ini dapat dipaparkan analisis pengaruh variabel bebas terhadap variable terikat, sebagai berikut:

1. Pengaruh Kompensasi, Gaya Kepemimpinan, dan Iklim Organisasi terhadap Kinerja 
karyawan di LP3I Karang Tengah, Ciledug.

- Model regresi berganda pada penelitian ini

$Y=3,233+0,172 X_{1}+0,240$

$\mathrm{X}_{2}+\mathbf{0 , 1 0 4} \mathrm{X}_{3}$

Model regresi berganda ini memberikan kesimpulan bahwa, jika faktor $\mathbf{X}_{\mathbf{1}}$ dan $\mathbf{X}_{\mathbf{2}}$ konstan, maka kenaikan satu satuan $\mathbf{X}_{\mathbf{3}}$ (variabel bebas iklim organisasi) akan meningkatkan Y (kinerja karyawan) sebesar 0,104 satuan. Jika faktor $\mathbf{X}_{\mathbf{2}}$ dan $\mathbf{X}_{\mathbf{3}}$ konstan, maka kenaikan satu satuan $\mathbf{X}_{\mathbf{1}}$ (variabel bebas kompensasi) akan meningkatkan Y (kinerja karyawan) sebesar 0,172 satuan. Jika faktor $\mathbf{X}_{\mathbf{1}}$ dan $\mathbf{X}_{\mathbf{3}}$ konstan, maka kenaikan satu satuan $\mathbf{X}_{\mathbf{2}}$ (variabel gaya kepemimpinan) akan meningkatkan Y (kinerja karyawan) sebesar 0,240 satuan.

- $\quad \mathrm{R}^{2}$ sebesar 0,701

Data tersebut mengindikasikan bahwa faktor kompensasi, gaya kepemimpinan dan iklim organisasi memberikan kontribusi positif sebesar 70,1\% terhadap kinerja karyawan, selebihnya $29,9 \%$ akibat faktor lain yang tidak diteliti.

- Nilai F (F-hitung) sebesar 10.034 dengan p.sig. 0,039

Nilai $\mathrm{F}$ table $=3,33$

Daerah kritis, $\quad \mathrm{H} 1=\mathrm{H} 2=\mathrm{H} 3=0$ ditolak jika p.sig. $<0,05$

Karena F-hitung $>\mathrm{F}$ tabel dan p.sig. $<0,05, \quad$ maka $\mathrm{H} 1=\mathrm{H} 2=\mathrm{H} 3=0$ ditolak dan $\mathrm{H} 1=\mathrm{H} 2=\mathrm{H} 3 \neq 0$ dterima

Hasil ini membuktikan bahwa terdapat pengaruh yang signifikan dari faktor kompensasi, gaya kepemimpinan dan iklim organisasi secara bersama-sama terhadap kinerja karyawan di LP3I Karang Tengah, Ciledug. Dari model regresi berganda ini juga diketahui bahwa faktor Gaya Kepemimpinan merupakan faktor paling dominan yang mempengaruhi

kinerja karyawan di LP3I Karang Tengah, Ciledug.

2. Pengaruh Faktor Kompensasi Terhadap Kinerja karyawan di LP3I Karang Tengah, Ciledug.

- Korelasi antara variabel $\mathbf{X}_{\mathbf{1}}$ dan Y adalah 0,188

Adanya hubungan positif sebesar 0,188 antara faktor kompensasi dan kinerja karyawan di LP3I Karang Tengah, Ciledug.

- $\quad \mathrm{R}^{2}$ sebesar 0,002

Data tersebut mengidentifikasikan bahwa faktor kompensasi memberikan kontribusi positif sebesar $2 \%$ terhadap kinerja karyawan.

3. Pengaruh Faktor Gaya Kepemimpinan Terhadap Kinerja Karyawan di LP3I Karang Tengah, Ciledug.

- Korelasi antara variabel $\mathbf{X}_{\mathbf{2}}$ dan Y adalah 0,251

Adanya hubungan positif sebesar 0.251 antara faktor gaya kepemimpinan dan kinerja karyawan di LP3I Karang Tengah, Ciledug.

- $\quad \mathrm{R}^{2}$ sebesar 0,560

Data tersebut mengidentifikasikan bahwa faktor gaya kepemimpinan memberikan kontribusi positif sebesar 56\% terhadap kinerja karyawan. 
4. Pengaruh Faktor Iklim Organisasi Terhadap Kinerja Karyawan di LP3I Karang Tengah, Ciledug.

- Korelasi antara variabel $\mathbf{X}_{\mathbf{3}}$ dan Y adalah 0,123

Adanya hubungan positif sebesar 0.123 antara faktor iklim organisasi terhadap kinerja karyawan di LP3I Karang Tengah, Ciledug.

- $\quad \mathrm{R}^{2}$ sebesar 0,046

Data tersebut mengidentifikasikan bahwa faktor iklim organisasi memberikan kontribusi positif sebesar 4,6\% terhadap kinerja karyawan.

\section{KESIMPULAN DAN SARAN}

\section{A. Kesimpulan}

Berdasarkan analisis dan pembahasan hasil penelitian serta mengacu pada maksud dan tujuan penelitian, seperti yang telah dipaparkan pada bab sebelumnya, maka dapat ditarik kesimpulan sebagai berikut:

Variabel kompensasi $\left(\mathrm{X}_{1}\right)$ terdapat pengaruh yang positif dan signifikan terhadap kinerja karyawan (Y) dengan nilai koefisien sebesar 0,172 . Artinya jika variabel kompensasi $\left(\mathrm{X}_{1}\right)$ meningkat satu satuan dengan asumsi variabel gaya kepemimpinan $\left(\mathrm{X}_{2}\right)$ dan variabel iklim organisasi $\left(\mathrm{X}_{3}\right)$ tetap, maka kinerja karyawan akan meningkat sebesar 0,172 .

Variabel Gaya Kepemimpinan $\left(\mathrm{X}_{2}\right)$ terdapat pengaruh yang positif dan signifikan terhadap kinerja karyawan (Y) dengan nilai koefisien sebesar 0,240 . Yang artinya jika variabel gaya kepemimpinan $\left(\mathrm{X}_{2}\right)$ meningkat satu satuan dengan asumsi variabel kompensasi $\left(\mathrm{X}_{1}\right)$ dan variabel iklim organisasi $\left(\mathrm{X}_{3}\right)$ tetap, maka kinerja karyawan (Y) akan meningkat sebesar 0,240 .

Variabel iklim organisasi $\left(\mathrm{X}_{3}\right)$ terdapat pengaruh yang positif dan signifikan terhadap kinerja karyawan (Y) dengan nilai koefisien sebesar 0,104 . Yang artinya jika variabel iklim organisasi $\left(\mathrm{X}_{3}\right)$ meningkat satu satuan dengan asumsi variabel kompensasi $\left(\mathrm{X}_{1}\right)$ dan variabel gaya kepemimpinan $\left(\mathrm{X}_{2}\right)$ tetap, maka kinerja karyawan $(\mathrm{Y})$ akan meningkat sebesar 0,104.

Faktor kompensasi, gaya kepemimpinan, dan iklim organisasi secara bersama-sama terdapat pengaruh yang positif dan signifikan terhadap kinerja karyawan di LP3I Karang Tengah, Ciledug.

Model regresi berganda yang diperoleh adalah

$\mathrm{Y}=3.233+0,172 \mathrm{X}_{1}+0,240 \mathrm{X}_{1}+$ $0,104 \mathrm{X}_{3}$

Dari data-data tersebut diatas didapat bahwa faktor Gaya Kepemimpinan mempunyai kontribusi yang paling besar pengaruhnya terhadap kinerja karyawan di LP3I Karang Tengah, Ciledug. Jika faktor kompensasi dan iklim organisasi konstan, maka kenaikan sebesar satu satuan $\mathrm{X}_{2}$ (variabel gaya kepemimpinan) menghasilkan kenaikan Y (kinerja karyawan) sebesar 0,240 satuan.

\section{Saran}

Berdasarkan kesimpulan yang telah dipaparkan diatas, berikut adalah saran-saran yang dapat dilaksanakan:

LP3I Karang Tengah perlu meningkatkan standard kompensasi untuk karyawannya seperti memberikan gaji sesuai dengan jenjang pendidikan dan kompetensi, memberikan kenaikan gaji yang signifikan setiap tahunnya, 
memberikan tunjangan jabatan yang standard.

LP3I Karang Tengah perlu adanya sosok pemimpin yang dapat memotivasi karyawannya baik dari aspek tehnis pekerjaan maupun kersejahteraan karyawan serta pemimpin yang mampu berkomunikasi baik kepada karyawan maupun investor.

LP3I Karang Tengah perlu menciptakan kondisi lingkungan kerja yang nyaman baik dari aspek komunikasi antara pimpinan dan bawahan maupun antara sesama karyawan.

LP3I Karang Tengah perlu meningkatkan SDM yang ada dengan memberikan kesempatan untuk meningkatkan jenjang karier serta memberikan pelatihan-pelatihan untuk mengembangkan potensi karyawan.

LP3I Karang Tengah perlu meningkatkan fasilitas dan kondisi alat kerja yang maksimal untuk mendukung kinerja karyawan.

LP3I Karang Tengah perlu memperbaiki system di manajemenya, karena system yang sekarang tidak berjalan sesuai dengan struktur organisasi yang ada karena masih ada campur tangan dari investor sebagai ownernya baik dalam pengambilan keputusan maupun kebijakan-kebijakan khususnya dalam hal kebijakan keuangan perusahaan, sehingga pimpinan tidak sepenuhnya mendapatkan wewenang. R2 sebesar 0 , 560. Data tersebut mengidentifikasikan bahwa faktor gaya kepemimpinan memberikan kontribusi positif sebesar $56 \%$ terhadap kinerja karyawan.

\section{Daftar Pustaka}

Arikunto. S. "Manajemen Penelitian". Penerbit Rineka Cipta. Jakarta. 2007.

Budiyono, A. H. "Pengantar Manajemen", Penerbit Graha Ilmu. Yogyakarta. 2003

Getut Pramesti. "Sukses Mengolah Data di Bidang Bisnis dan Industri dengan SPSS 16.00". Penerbit Elexmedia Komputindo. Jakarta. 2009.

Handoko, T. H. "Manajemen Edisi 2". Penerbit BPFE. Yogyakarta. 2010.

Hasibuan, M. S. P. "Manajemen Sumber Daya Manusia. Penerbit Bumi Aksara. Jakarta. 2009.

Mangkunegara. A, Anwar Prabu. "MSDM Cetakan Pertama". Penerbit Remaja Rosda Karya. Bandung. 2000.

Nazir, Moh. "Metode Penelitian". Penerbit Ghalia Indonesia. Bogor. 2005.

Rachmawati, I. K. "Manajemen Sumber Daya Manusia". Penerbit Andi. Yogyakarta. 2008.

Riduwan. "Belajar Mudah Penelitian Untuk Guru, Karyawan dan Peneliti Pemula". Penerbit Alfabeta. Bandung. 2005.

Sedarmayanti. "Manajemen Sumber Daya Manusia (Reformasi Birokrasi dan Manajemen Pegawai Negeri Sipil)". Penerbit Rafika Aditama. Bandung. 2007

Sugiyono. "Statistik Untuk Penelitian ". Penerbit Alfabeta. Bandung. 2006. 